\title{
Haplosporidiosis in the Pacific oyster Crassostrea gigas from the French Atlantic coast
}

\author{
Tristan Renault ${ }^{1, *}$, Nancy A. Stokes ${ }^{2}$, Bruno Chollet $^{1}{ }^{\text {, Nathalie Cochennec }}{ }^{1}$, \\ Franck Berthe ${ }^{1}$, André Gérard ${ }^{1}$, Eugene M. Burreson ${ }^{2}$ \\ ${ }^{1}$ IFREMER, Laboratoire de Génétique et Pathologie, BP 133, 17390 La Tremblade, France \\ ${ }^{2}$ Virginia Institute of Marine Science, College of William and Mary, Gloucester Point, Virginia 23062, USA
}

\begin{abstract}
Two cases of haplosporidian infection occurred during 1993 in Pacific oysters Crassostrea gigas from the French Atlantic coast. The localization and ultrastructure of the plasmodia are described. In situ hybridization of infected tissue sections was conducted with DNA probes for oysterinfecting haplosporidians. The Haplosporidium nelsoni-specific DNA probe MSX1347 hybridized with the C. gigas parasite, and the $H$. costale-specific probe SSO1318 did not hybridize. Total genomic DNA was extracted from the infected tissue sections for polymerase chain reaction (PCR) amplification of the haplosporidian. PCR amplifications with $H$. nelsoni-specific primers and with 'universal' actin primers did not yield the expected products of 573 and $700 \mathrm{bp}$, respectively. A series of primers was designed to amplify short regions of small subunit ribosomal DNA (SSU rDNA) from most haplosporidians. The primers encompass a highly variable region of the SSU rDNA and did not amplify oyster DNA. PCR amplification of the infected C. gigas genomic DNA with these primers yielded the expected-sized product from the primer pair targeting the shortest region (94 bp). This PCR product was sequenced and it was identical to the corresponding SSU rDNA region of $H$. nelsoni.
\end{abstract}

KEY WORDS: Pacific oyster · Crassostrea gigas $\cdot$ Haplosporidiosis $\cdot$ Haplosporidium nelsoni

\section{INTRODUCTION}

Haplosporidian parasites can infect several species of oysters. Haplosporidium nelsoni and $H$. costale cause extensive mortalities of the eastern oyster Crassostrea virginica on the east coast of the United States (Andrews 1966). Haplosporidian parasites also occur in European flat oysters Ostrea edulis (Van Banning 1977, Pichot et al. 1979, Cahour et al. 1980, Vivares et al. 1982, Bachère \& Grizel 1983), Olympia oysters $O$. lurida (Mix \& Sprague 1974), pearl oysters Pinctada maxima (Hine \& Thorne 1998), and Pacific oysters $C$. gigas (Rosenfield et al. 1966, Katkansky \& Warner 1970, Kern 1976, Comps \& Pichot 1991, Friedman et al. 1991, Friedman 1996, Burreson et al. 2000). For these affected bivalve species, there is no evidence that the

\footnotetext{
*E-mail: trenault@ifremer.fr
}

haplosporidian parasites are responsible for significant mortality similar to those reported among eastern oysters C. virginica; however, Katkansky \& Warner (1970) described a heavy haplosporidian infection in the connective tissues of a moribund Pacific oyster.

Haplosporidian parasites have been detected in Pacific oysters from different parts of the world, including Korea (Kern 1976), Taiwan (Rosenfield et al. 1966), Japan (Friedman et al. 1991, Friedman 1996), California, USA (Friedman 1996), and France (Comps \& Pichot 1991), during routine histological examination for bivalve parasites. In this study, the discovery of haplosporidian plasmodial stages is reported in juvenile Pacific oysters from the French Atlantic coast during epizootiological surveys for bivalve pathogens. The lack of spores in infected oysters prohibited positive identification by morphological criteria; therefore, DNA-based diagnostics were used to identify the haplosporidian as Haplosporidium nelsoni. 


\section{MATERIALS AND METHODS}

Source of specimens. 617 adult and 174 juvenile cultured Pacific oysters Crassostrea gigas were collected for routine histological surveys from different locations along the French Atlantic coast between January 1993 and October 1993.

Light microscopy. Oysters were examined for condition and gross signs of disease. After individuals were removed from the shell, they were sagitally sectioned, then half was placed in Davidson's fixative and the other half in Carson's fixative. Samples fixed in Davidson's fixative were dehydrated through an ascending ethanol series, cleared in xylene and infiltrated in paraffin in a tissue processor. Following these steps, samples were embedded in paraffin, sectioned at 3 or $4 \mu \mathrm{m}$ thickness, stained by hematoxylin and eosin (H\&E) and carefully checked for lesions and parasites.

Electron microscopy. Pieces of gill and digestive gland tissue stored in Carson's fixative were rinsed for $48 \mathrm{~h}$ in $0.2 \mathrm{M}$ cacodylate buffer, fixed in $2.5 \%$ glutaraldehyde in $0.2 \mathrm{M}$ cacodylate buffer at $\mathrm{pH} 7.2$ and post-fixed in $1 \%$ osmium tetroxide in the same buffer. Specimens were dehydrated in an ascending ethanol series, cleared in propylene oxide and embedded in Epon resin. Blocks were cut on a LKB ultramicrotome. One $\mu \mathrm{m}$ thick sections for light microsopy were stained in $2.5 \%$ toluidine blue in $1 \%$ aqueous sodium borate solution. Ultra thin sections were collected on copper grids and double stained with uranyl acetate and lead citrate (Reynolds 1963) and observed in a JEOL JEM 1200 EX transmission electron microscope at $60 \mathrm{kV}$.

In situ hybridization. In situ hybridization was performed on Davidson's fixed, paraffin-embedded tissue of the oyster collected at Morlaix using $5 \mathrm{ng}^{-1} \mathrm{l}^{-1}$ of the Haplosporidium costale-specific DNA probe SSO1318 or the H. nelsoni-specific DNA probe MSX1347, as described elsewhere (Stokes \& Burreson 1995). These probes, which target one of the variable regions of the small subunit ribosomal RNA (SSU rRNA) gene are sensitive and specific for the target organisms (Stokes \& Burreson 1995, 1999). Positive control in situ hybridizations consisted of tissue sections of Crassostrea virginica infected with $H$. costale, collected from Burton Bay, on the Atlantic coast of Virginia, in May 1984 and $C$. virginica infected with $H$. nelsoni, collected from York River, a tributary of the lower Chesapeake Bay, in Virginia in November 1995. Negative controls contained no probe in the hybridization solution.

Polymerase chain reaction (PCR). DNA was isolated from tissue sections of the Morlaix oyster by 3 different methods, as previously described (Wright \& Manos 1990, Vachot \& Monnerot 1996, Shedlock et al. 1997). The genomic DNA isolated from each of these methods was subjected to PCR amplification using Haplospo- ridium nelsoni-specific primers MSX-A' and MSX-B (Table 1). PCR reaction mixtures contained reaction buffer (10 mM Tris, $\mathrm{pH} 8.3 ; 50 \mathrm{mM} \mathrm{KCl} ; 1.5 \mathrm{mM} \mathrm{MgCl}_{\text {; }}$ $10 \mu \mathrm{g} \mathrm{ml}^{-1}$ gelatin), $400 \mu \mathrm{g} \mathrm{ml}^{-1}$ bovine serum albumin, $25 \mathrm{pmol}$ of each primer, $200 \mu \mathrm{M}$ each of dATP, dCTP, dGTP, dTTP, 0.6 units AmpliTaq DNA polymerase (Perkin-Elmer), and template DNA in a total volume of $25 \mu \mathrm{l}$. The MSX-A' + B reaction mixtures were cycled in a GeneAmp PCR System 9600 thermal cycler (Perkin-Elmer) 35 times at $94^{\circ} \mathrm{C}$ for $30 \mathrm{~s}, 59^{\circ} \mathrm{C}$ for $30 \mathrm{~s}$, and $72^{\circ} \mathrm{C}$ for $1.5 \mathrm{~min}$ with final extension at $72^{\circ} \mathrm{C}$ for 5 min. Genomic DNA was tested for amplifiability using 'universal' eukaryotic actin gene primers 480 and 483 designed by G. Warr (Medical University of South Carolina) and M. Wilson (Mississippi State Medical Center). Amplification of oyster genomic DNA with these primers yields an expected product of about $700 \mathrm{bp}$. The actin PCR reaction mixtures were prepared and cycled as above, except the annealing temperature was $45^{\circ} \mathrm{C}$ and extension temperature was $65^{\circ} \mathrm{C}$. Lack of amplifiability with either the $H$. nelsonispecific primers or the actin primers prompted design of a series of primers that would amplify small regions of the small subunit ribosomal DNA (SSU rDNA) (approximately 90 to $360 \mathrm{bp}$ ) of most haplosporidians. The PCR primers, designated HAP-F1, HAP-F2, HAPR1, HAP-R2, and HAP-R3 (Table 1), encompassed the variable region targeted by the DNA probes MSX1347 and SSO1318. The HAP PCR reaction mixtures were prepared and cycled as described above, except the annealing temperature was $48^{\circ} \mathrm{C}$ for the HAP-F1 reactions and $44^{\circ} \mathrm{C}$ for the HAP-F2 reactions and the extension time was $1 \mathrm{~min}$ per cycle. An aliquot $(10 \%$ of reaction volume) of each PCR reaction was checked for amplification product by agarose gel electrophoresis and ethidium bromide staining (see Table 2).

Sequencing. PCR product was ethanol precipitated, ligated into the plasmid vector pCR2.1 (Invitrogen),

Table 1. PCR primers. MSX-A' is MSX-A with an additional 8 bases at the $5^{\prime}$ end; the latter primer, along with MSX-B, was reported previously (Stokes et al. 1995). MSX-A' and MSX-B are Haplosporidium nelsoni-specific, targeting a 565 bp region of the SSU rDNA. The HAP primers amplify small regions of the SSU rDNA of most haplosporidians. All of the HAP amplification products encompass the variable region targeted by the $H$. nelsoni and $H$. costale DNA probes

\begin{tabular}{ll} 
Primer name & Primer sequence $\left(5^{\prime}-3^{\prime}\right)$ \\
\hline MSX-A & CGACTTTGGCATTAGGTTTCAGACC \\
MSX-B & ATGTGTTGGTGACGCTAACCG \\
HAP-F1 & GTTCTTTCWTGATTCTATGMA \\
HAP-F2 & GCCRTCTAACTAGCTS \\
HAP-R1 & CTCAWKCTTCCATCTGCTG \\
HAP-R2 & GATGAAYAATTGCAATCAYCT \\
HAP-R3 & AKRHRTTCCTWGTTCAAGAYGA
\end{tabular}


Table 2. Expected PCR product sizes from haplosporidian DNA with the primer pairs listed. Oyster (Crassostrea gigas or C. virginica) DNA does not yield amplification product with any of these primer pairs

\begin{tabular}{|c|c|c|c|}
\hline \multirow[t]{2}{*}{ Primer pair } & \multicolumn{3}{|c|}{ Expected PCR product (bp) } \\
\hline & Haplosporidium nelsoni & H. costale & Minchinia teredinis \\
\hline MSX-A' + MSX-B & 573 & None & None \\
\hline HAP-F1 + HAP-R1 & 186 & 191 & 185 \\
\hline HAP-F1 + HAP-R2 & 331 & 336 & 327 \\
\hline HAP-F1 + HAP-R3 & 348 & 353 & 344 \\
\hline HAP-F2 + HAP-R1 & 94 & 99 & 93 \\
\hline HAP-F2 + HAP-R2 & 239 & 244 & 235 \\
\hline HAP-F2 + HAP-R3 & 256 & 261 & 252 \\
\hline
\end{tabular}

and transformed into Escherichia coli INVF' cells. Clones with inserts were cycle sequenced via simultaneous bidirectional sequencing using M13 forward and reverse primers labeled with the fluorescent dyes IRD-700 and IRD-800 (LI-COR). Sequencing reactions were electrophoresed on a $41 \mathrm{~cm} 5 \%$ polyacrylamide gel in a Li-Cor Model 4200 automated sequencer. Sequence data were aligned with haplosporidian SSU rDNA sequences using the MacVector software package (Oxford Molecular).

\section{RESULTS}

\section{Pathology}

Adult oysters appeared gravid or in different stages of gonad resorption during the sampling period. Histological examination of stained sections showed the presence of haplosporidian-like infections within the digestive gland and gill connective tissues of juvenile oysters. Among the 791 individuals examined, 2 were found infected (prevalence $0.27 \%$ ): a 7 mo old spat from Arcachon Bay (south French Atlantic coast-July 1993) and a 14 mo old individual collected in Morlaix area (Brittany-August 1993). This oyster had been transferred to Brittany from Arcachon Bay. The protozoan infection was accompanied by infiltration of host hemocytes into the areas of parasitic infection. Numerous early plasmodial stages ( 2 to 8 nuclei), 8 to $15 \mu \mathrm{m}$ in diameter, were found in connective tissues of gills and digestive gland (Fig. 1). No sporogonic stages or spores were observed. The normal architecture of affected tissues was altered; necrosis and cell lysis were observed within host tissues surrounding parasites.

\section{Electron microscopy}

Electron microscopic examination showed uni- and multinucleated plasmodia, 8 to $15 \mu \mathrm{m}$ in diameter, scattered in connective tissues of gills and digestive gland (Fig. 2). Uninucleated and binucleated forms were the most frequently seen (Figs. 3 \& 4), multinucleated plasmodia (more than 2 nuclei) were rarely observed (Fig. 5). Parasitic cells at this development stage were not delimited by a wall. The fine structure of plasmodia in affected tissues was diverse; however, most plasmodial stages possessed osmophilic round bodies 150 to $180 \mathrm{~nm}$ in diameter scattered throughout the cytoplasm (Figs. 2, 4 \& 5). These structures were limited by a membrane and identified by an inner electron-lucent configuration usually having appearance of a 'squat vase' (Fig. 6). The area within this configuration was usually not as electron-dense as the area to its exterior. The haplosporidian electron-dense bodies or haplosporosomes were physically asociated with membrane-limited regions and numerous membrane 'spherules'. The round dense bodies appeared to bud off from these areas (Fig. 7). The number of haplosporosomes within any given plasmodium varied greatly, but these structures were often abundant (average $51 \pm 19, \mathrm{n}=20$, per plasmodium section). An additional structure consistently found in the plasmodium cytoplasm was round, approximately $130 \mathrm{~nm}$ in diameter, membrane-limited, and had a dense core which appeared to be connected to the periphery by fine radiating fibers arranged in a spike-like fashion (Fig. 8). The cytoplasmic fine structure included large distended oval or round mitochondria with vesicular cristae (Figs. 3, 4 \& 5). Endoplasmic reticulum was sparse and free of ribosomes, the latter being found in high density in the

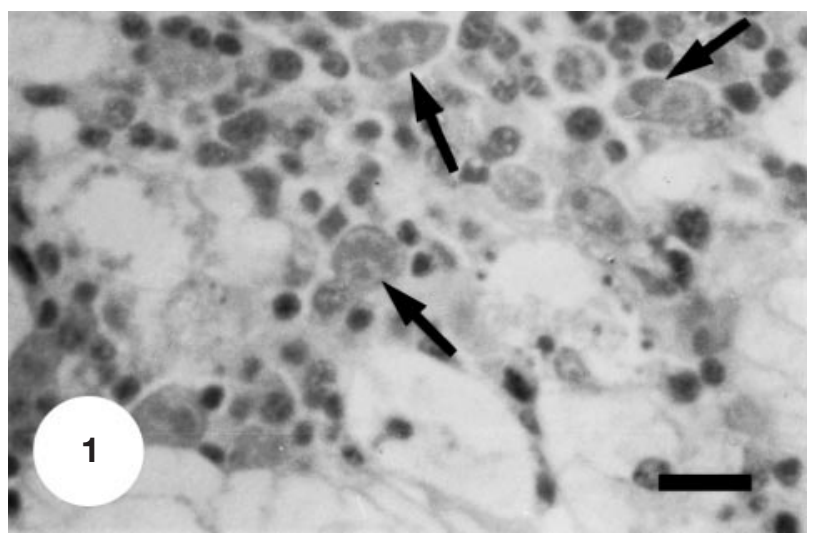

Fig. 1. Haplosporidian parasitizing Crassostrea gigas. Early plasmodial stages in connective tissue of the digestive gland (arrows). Light microscopy. H\&E stain. Scale bar $=1 \mu \mathrm{m}$ 

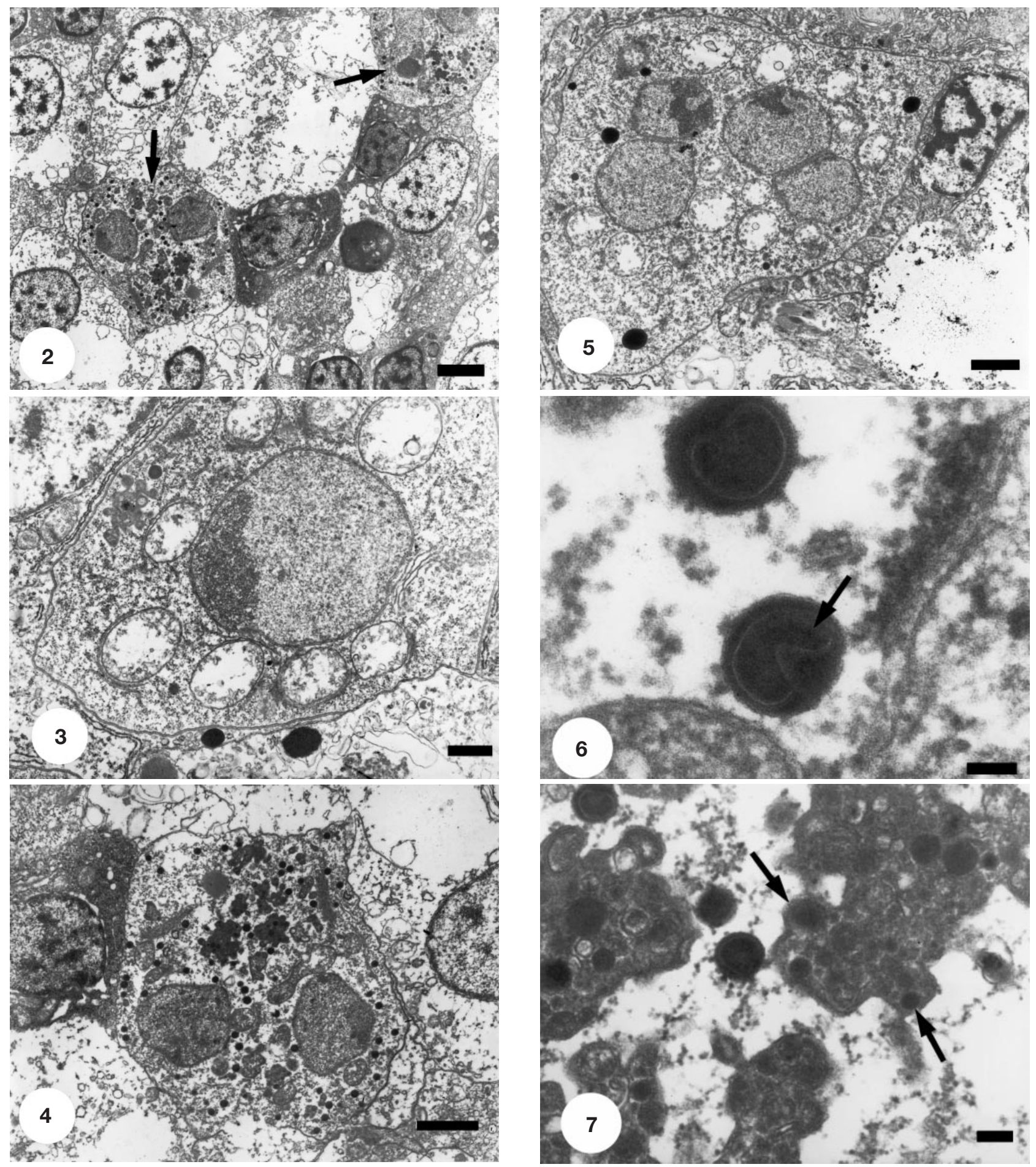

Figs. 2 to 7. Electron micrographs of haplosporidian parasitizing Crassostrea gigas. Fig. 2. Uni- and multinucleated plasmodia in connective tissue of the digestive gland (arrows). Scale bar $=2 \mu \mathrm{m}$. Fig. 3. Uninucleated plasmodium. Scale bar $=500 \mathrm{~nm}$. Fig. 4. Binucleated plasmodium. Scale bar $=1 \mu \mathrm{m}$. Fig. 5. Multinucleated plasmodium. Scale bar $=1 \mu \mathrm{m}$. Fig. 6 . High magnification $\overline{\text { of haplosporosomes. Note internal electron-lucent configuration of polar-oriented haplosporosomes (arrow) }}$. Scale bar $=50 \mathrm{~nm}$. Fig. 7. Budding off of haplosporosomes from electron-dense areas (arrows). Scale bar $=200 \mathrm{~nm}$ 


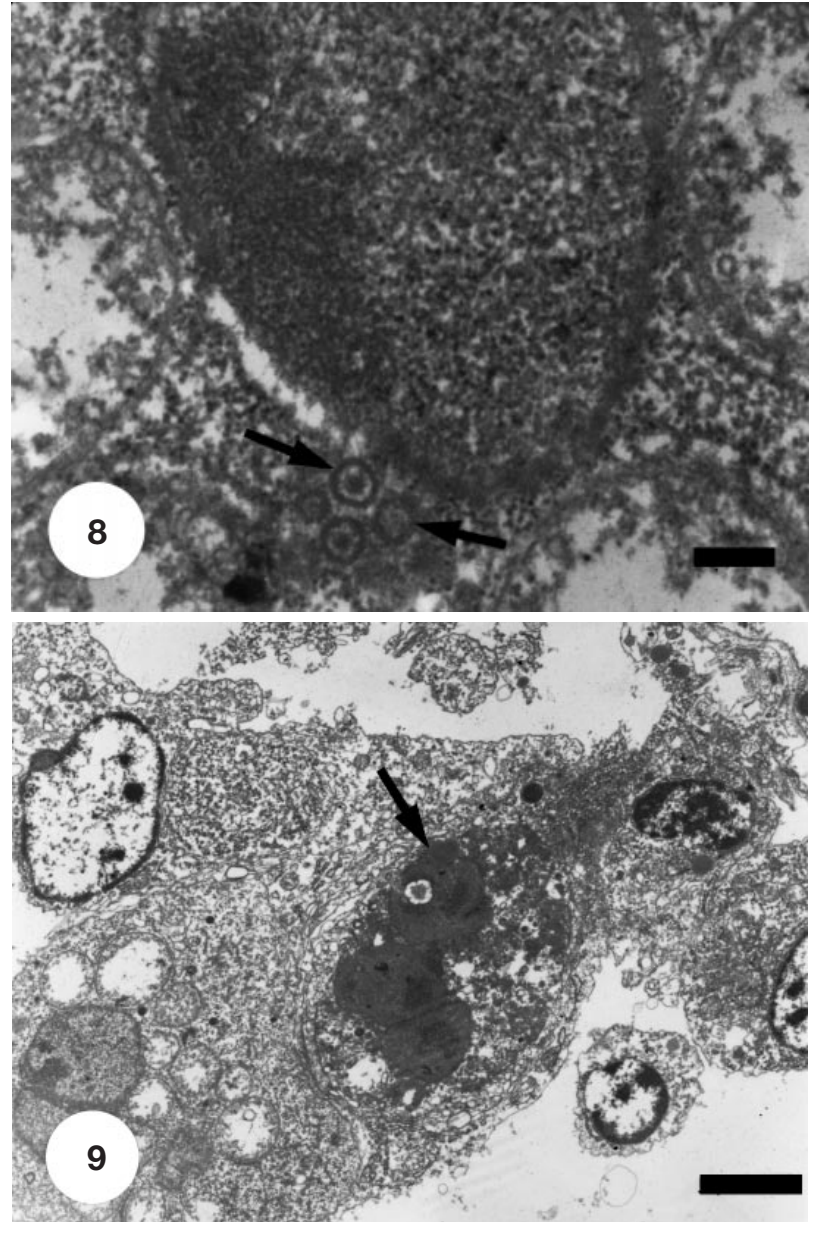

Figs. 8 \& 9. Fig. 8. Concentric bodies in the plasmodium cytoplasm (arrows). Scale bar $=200 \mathrm{~nm}$. Fig. 9. Degenerating plasmodium containing pycnotic nuclei, swollen mitochondria and leached plasma membranes (arrows). Scale bar $=2 \mu \mathrm{m}$

ground cytoplasm. The nuclei were usually paired and each was characterized by a single prominant endosome which was round or oval and against the nuclear envelope (Figs. 4 \& 5). The nucleal Feulgen and Rossenbeck reaction indicated primarily peripheral location of the DNA. Degenerating parasites were occasionally found with pycnotic nuclei, swollen mitochondria and leached plasma membranes (Fig. 9).

\section{DNA-based assays}

In situ hybridization of DNA probe MSX1347 (Haplosporidium nelsoni) to infected oyster tissue sections yielded strong hybridization of the probe to plasmodia, while DNA probe SSO1318 (H. costale) did not hybridize (Fig. 10). Both probes hybridized with the plasmodia in the respective postive controls (data not shown). Repeated attempts to amplify DNA isolated from tissue sections were unsuccessful using the 'universal' actin primers and the $H$. nelsoni-specific primers, MSX-A' and MSX-B. Consequently, the HAP primers were developed to specifically amplify smaller regions of haplosporidian SSU rDNA from infected host tissue DNA. All 6 HAP primer pair combinations were used in PCR amplifications of the Morlaix oyster tissue DNA; only HAP-F2 + HAP-R1 yielded PCR product, which was the size expected for a haplosporidian (Table 2). Eight clones of the PCR product were sequenced. The sequence was 94 bases long and was identical to the published sequence for bases 1305 to 1398 of the H. nelsoni SSU rDNA.

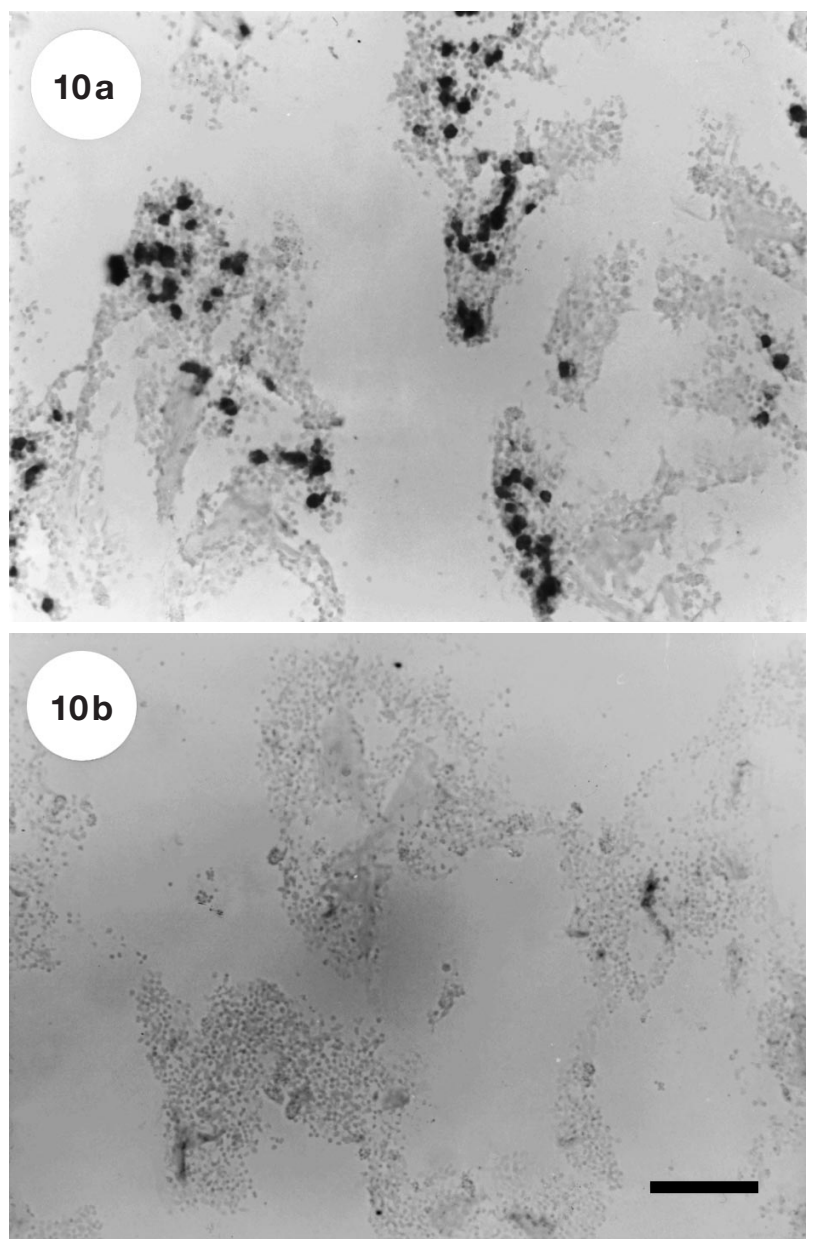

Fig. 10. In situ hybridizations with DNA probes on adjacent tissue sections of haplosporidian-infected Crassostrea gigas collected in Morlaix. Scale bar $=100 \mu \mathrm{m}$. (a) Positive reaction with plasmodia using $5 \mathrm{ng}^{-1} \mathrm{l}^{-1}$ of Haplosporidium nelsonispecific probe MSX1347. (b) Absence of reaction with plas-

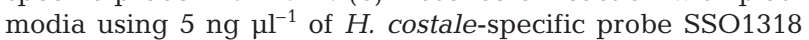




\section{DISCUSSION}

The haplosporidian parasite observed in Crassostrea gigas from the French Atlantic coast is similar to Haplosporidium nelsoni of $C$. virginica in tissue location, morphology and size of plasmodial stages. Infection with the haplosporidian parasite is characterized by the presence of uni- and multinucleated plasmodia througout gill, gonad and digestive gland connective tissues. Parasites elicit a hemic response. These observations are consistent with early systemic infections of $H$. nelsoni (Andrews 1966, Perkins 1968, 1969). The dense bodies reported here are typical of those observed in the cytoplasm of $H$. nelsoni plasmodial stages (Scro \& Ford 1990), in contrast with the round, oval or pyriform haplosporosomes of H. costale (Perkins 1969). In addition to difference in shape, the electron-dense bodies of $H$. costale were found less abundantly than those in $H$. nelsoni. Such differences were used to help distinguish the plasmodia of both species; for example, a section through a $H$. nelsoni plasmodium often showed more than 70 free electron-dense bodies, whereas in a comparable sized plasmodial section of $H$. costale a maximum of 15 structures were counted (Perkins 1968, 1969). The average number of haplosporosomes counted here (51) is more comparable to the number 70, previously observed in $H$. nelsoni plasmodia, than to the 15 observed in $H$. costale plasmodia (Perkins 1968, 1969). The amount of haplosporosomes within plasmodia in C. gigas, however, varied greatly per parasite section (Perkins 1968, 1969). The additional structures seen in the cytoplasm of $C$. gigas haplosporidian parasites are similar to the 'concentric bodies' described by Scro \& Ford (1990) in the H. nelsoni cytoplasm.

Results of the DNA-based diagnostic assays supported each other. Plasmodia in the Morlaix Crassostrea gigas sample hybridized only with the Haplosporidium nelsoni-specific DNA probe MSX1347 and the sequence of the PCR-amplified DNA was identical to the corresponding SSU rDNA sequence of $H$. nelsoni. Even though DNA isolated from tissue sections of the oyster collected from Morlaix was not amplifiable with the primer pairs MSX-A' + MSX-B or actin $480+483$, it did yield amplification product with the haplosporidian SSU rDNA primers HAP-F2 + HAP-R1. This is consistent with observations that PCR amplification of target regions greater than 200 to $500 \mathrm{bp}$ is very difficult to achieve on DNA from archival samples, due to fragmentation of DNA and crosslinking of histones to DNA during formaldehyde fixation of tissues (Pääbo 1990, Hamazaki et al. 1993, Vachot \& Monnerot 1996).

DNA-based diagnostics have been used previously (Burreson et al. 2000) to identify haplosporidian plas- modia that were detected in Crassostrea gigas from Korea (Kern 1976) and Japan and California, USA (Friedman 1996). Lack of sporogonic stages in the latter survey precluded definite identification of the haplosporidian. Therefore, in situ hybridizations using MSX1347, the same DNA probe used in this study, were performed on paraffin-embedded tissue sections of the infected oysters from Japan and California, and one of the non-sporulating oysters from Korea. The Haplosporidium nelsoni probe hybridized with haplosporidian plasmodia in all of these oysters (Burreson et al. 2000). In addition, genomic DNA was isolated from the infected California oysters and subjected to PCR amplification with the primers MSX-A and MSXB (Stokes et al. 1995). DNA from the California oysters amplified with the $H$. nelsoni PCR primers and the $565 \mathrm{bp}$ sequence was identical to the $H$. nelsoni SSU rDNA target region, with only one nucleotide difference (Burreson et al. 2000). In this study, the $H$. nelsoni primers MSX-A' (same as MSX-A, but with an additional 8 bases at the $5^{\prime}$ end) and MSX-B did not amplify the plasmodial DNA but the haplosporidian primers HAP-F2 and HAP-R1 did. Even though the PCR product generated by the HAP primers was shorter, it amplified a variable region of the SSU rDNA that contains sequence unique to each haplosporidian.

Tissues from the California oysters were fixed for only $24 \mathrm{~h}$ in neutral buffered formalin (Burreson et al. 2000), whereas tissues from the French oysters in this study were fixed for at least $1 \mathrm{wk}$ in Davidson's AFA. The former fixation treatment has been shown to yield DNA that can PCR amplify longer target regions than DNA from long-term storage in unbuffered fixative (Vachot \& Monnerot 1996). Davidson's AFA is the fixative of choice for marine invertebrates. Traditional fixation procedures include tissue storage in Davidson's AFA from $1 \mathrm{~d}$ up to a few months. Diagnosis of parasites by histological examination is not affected by this practice; however, the quality of DNA isolated from fixed tissues is reduced the longer those tissues are stored in fixative (Hamazaki et al. 1993, O'Leary et al. 1994). The HAP primers were developed in order to work with archived samples that were fixed for indeterminate periods. The smaller target regions are more amenable to PCR amplification and the primers specifically amplify most haplosporidians from the total genomic DNA isolated from infected hosts.

The morphological observations, in situ hybridization with the Haplosporidium nelsoni-specific probe, and sequence of the PCR amplified product that was identical to an SSU rDNA variable region of $H$. nelsoni confirm that the haplosporidian parasite in Crassostrea gigas from the French Atlantic coast is H. nelsoni or a 
very closely related parasite. Indeed, the molecular methods used can only confirm identification in relation to known species or strains. Other parasites for which sequence data are not available could conceivably give the same identification.

The prevalence of infected oysters found in this study was very low $(0.27 \%)$. The 2 infected oysters originated from the same area (Arcachon Bay, south Atlantic French coast). Other disease survey studies of Crassostrea gigas have found similarly low prevalences of haplosporidian infection. During a $4 \mathrm{yr}$ sampling of 1438 oysters from Korea, 4 (0.28\%) were infected with haplosporidians (Kern 1976). In a survey of C. gigas from Japan, 10/100 spat and 1/171 adult oysters were infected with haplosporidians that closely resembled Haplosporidium nelsoni (Friedman et al. 1991). In a subsequent study, Friedman (1996) observed haplosporidian infections in 1 to $3 \%$ of oysters from Japan and up to $7 \%$ of oysters from California. In 2 yr of routine surveys of C. gigas from Etang de Thau, France, Comps \& Pichot (1991) found 3 oysters infected with haplosporidians. Based on electron microscopic studies of the spores, the parasite seemed similar to $H$. costale. The low prevalence of haplosporidian parasite infections in $C$. gigas suggests that this oyster species is less sensitive to the infection than $C$. virginica and that $C$. gigas can react against the parasite and limit its spread. Moreover, early plasmodial stages are mainly observed in infected C. gigas oysters, suggesting that the parasite is not able to develop normally in this bivalve species.

Acknowledgements. This research was supported in part by the Région Poitou-Charentes (France). VIMS contribution number 2332 .

\section{LITERATURE CITED}

Andrews JD (1966) Oyster mortality studies in Virginia. V. Epizootiology of MSX, a protistan pathogen of oysters. Ecology 47:19-31

Bachère E, Grizel H (1983) Mise en évidence d'Haplosporidium sp. (Haplosporidia-Haplosporidiidae) parasite de l'huître plate Ostrea edulis L. Rev Trav Inst Pêches Marit 46(3):226-232

Burreson EM, Stokes NA, Friedman CS (2000) Increased virulence in an introduced pathogen: Haplosporidium nelsoni (MSX) in the eastern oyster, Crassostrea virginica. J Aquat Anim Health 12:1-8

Cahour A, Poder M, Balouet G (1980) Présence de Minchinia armoricana (Haplospores, Haplosporida) chez Ostrea edulis d'origine française. C R Seances Soc Biol Fil 174(3):359-368

Comps M, Pichot Y (1991) Fine spore structure of haplosporidian parasitizing Crassostrea gigas: taxonomic implications. Dis Aquat Org 11:73-77

Friedman CS (1996) Haplosporidian infections of the Pacific oyster Crassostrea gigas (Thunberg), in California and Japan. J Shellfish Res 15:597-600

Friedman CS, Cloney DF, Manzer D, Hedrick RP (1991)
Haplosporidiosis of the Pacific oyster Crassostrea gigas J Invertebr Pathol 58:367-372

Hamazaki S, Koshiba M, Habuchi T, Takahashi R, Sugiyama $\mathrm{T}$ (1993) The effect of formalin fixation on restriction endonuclease digestion of DNA and PCR amplification. Pathol Res Pract 189:553-557

Hine PM, Thorne T (1998) Haplosporidium sp. (Haplosporidia) in hatchery-reared pearl oysters, Pinctada maxima (Jameson, 1901), in north Western Australia. J Invertebr Pathol 71:48-52

Katkansky SC, Warner RW (1970) Sporulation of a haplosporidian in Pacific oyster (Crassostrea gigas) in Humboldt Bay, California. J Fish Res Board Can 27:1320-1321

Kern FG (1976) Sporulation of Minchinia sp. (Haplosporida, Haplosporidiidae) in the Pacific oyster Crassostrea gigas (Thunberg) from the Republic of Korea. J Protozool 23: 498-500

Mix MC, Sprague V (1974) Occurrence of a haplosporidian in native oysters (Ostrea lurida) from Yaquina Bay and Alsea Bay, Oregon. J Invertebr Pathol 23:251-254

O'Leary JJ, Browne G, Landers RJ, Crowley M, Bailey Healy I, Street JT, Pollock AM, Murphy J, Johnson MI, Lewis FA, Mohamdee O, Cullinane C, Doyle CT (1994) The importance of fixation procedures on DNA template and its suitability for solution-phase polymerase chain reaction and PCR in situ hybridization. Histochem J 26:337-346

Pääbo S (1990) Amplifying ancient DNA. In: Innis MA, Gelfand DH, Sninsky JJ, White TJ (eds) PCR protocols: a guide to methods and applications. Academic Press, San Diego, CA, p 159-166

Perkins FO (1968) Fine structure of the oyster pathogen Minchinia nelsoni (Haplosporida, Haplosporidiidae). J Invertebr Pathol 10:287-307

Perkins FO (1969) Electron microscope studies of sporulation in the oyster pathogen Minchinia costalis (Sporozoa: Haplosporida). J Parasitol 55(5):897-920

Pichot Y, Comps M, Deltreil JP (1979) Recherches sur Haplosporidium sp. (Haplosporida, Haplosporidiidae) parasite de l'huître plate Ostrea edulis L. Rev Trav Inst Pêches Marit 43(4):405-408

Reynolds ES (1963) The use of lead citrate at high $\mathrm{pH}$ as an electron-opaque stain in electron microscopy. J Cell Biol $17: 208-212$

Rosenfield A, Farley CA, Couch JA (1966) Parasites of Taiwan oysters. US Bur Comm Fish Man Report 66-68

Scro RA, Ford SE (1990) An electron microscope study of disease progression in the oyster Crassostrea virginica infected with the protozoan parasite Haplosporidium nelsoni (MSX). In: Perkins FO, Cheng TC (eds) Pathology in marine science. Academic Press, San Diego, CA, p 229-254

Shedlock AM, Haygood MG, Pietsch TW, Bentzen P (1997) Enhanced DNA extraction and PCR amplification of mitochondrial genes from formalin-fixed museum specimens. Biotechniques 22(3):394-400

Stokes NA, Burreson EM (1995) A sensitive and specific DNA probe for the oyster pathogen Haplosporidium nelsoni. J Eukaryot Microbiol 42:350-357

Stokes NA, Burreson EM (1999) Development and application of molecular diagnostics for the oyster pathogen Haplosporidium costale. European Association of Fish Pathologists 9th International Conference, Diseases of Fish and Shellfish, Abstract book, September 1999, Rhodes

Stokes NA, Siddall ME, Burreson EM (1995) Detection of Haplosporidium nelsoni (Haplosporidia: Haplosporidiidae) in oysters by PCR amplification. Dis Aquat Org 23: $145-152$ 
Vachot AM, Monnerot M (1996) Extraction, amplification and sequencing of DNA from formaldehyde-fixed specimens. Ancient Biomolecules 1:3-16

Van Banning P (1977) Minchinia armoricana sp. nov. (Haplosporida), a parasite of the European flat oyster Ostrea edulis. Invertebr Pathol 30:199-206

Vivares CP, Brehelin M, Cousserans F, Bonami JR (1982) Mise

Editorial responsibility: Albert Sparks,

Seattle, Washington, USA en évidence d'une nouvelle Haplosporidie parasite de l'huître plate Ostrea edulis L. C R Acad Sci Paris 295: 127-130

Wright DK, Manos MM (1990) Sample preparation from paraffin-embedded tissues. In: Innis MA, Gelfand DH, Sninsky JJ, White TJ (eds) PCR protocols: a guide to methods and applications. Academic Press, San Diego, CA, p 153-158

Submitted: February 22, 2000; Accepted: July 11, 2000

Proofs received from author(s): September 18, 2000 